\title{
Provenance of coarse ice-rafted detritus near the SE Greenland margin
}

\author{
K. Linthout ${ }^{1}$, S.R. Troelstra ${ }^{2} \&$ A. Kuijpers ${ }^{3}$
}

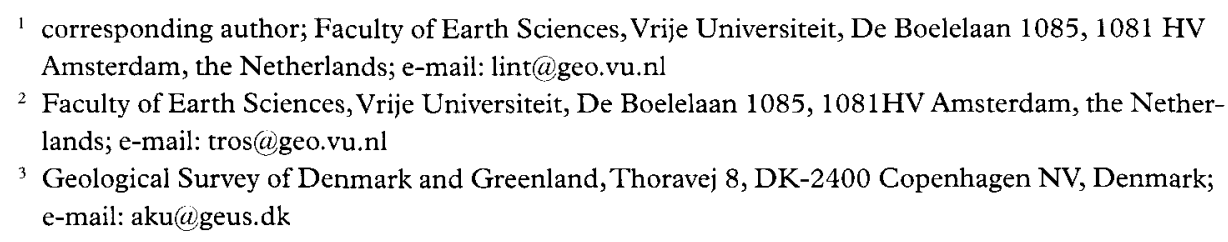

Received: 11 November 1999; accepted: in revised form 29 January 2000

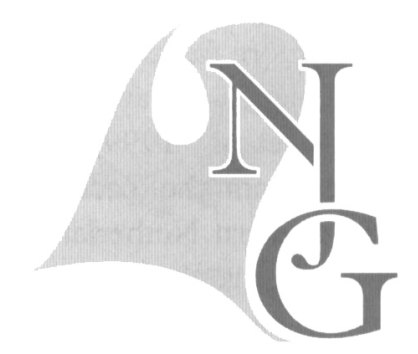

\begin{abstract}
The provenance of coarse-grained ice-rafted detritus has been studied, based on material collected from the SE Greenland margin. The sediment was sampled by a $1.5 \mathrm{~m}^{3}$ video-grab from $1256 \mathrm{~m}$ water depth. The fraction $>1 \mathrm{~cm}$ was macroscopically investigated and a thin-section analysis was made. The results clearly show that East Greenland north of the Denmark Strait is the source region of the material sampled. The main provenance is from areas adjoining Kangerdlugssuaq Fjord, Blosseville Kyst, Scoresby Sund, Kong Oskar Fjord, and Kejser Franz Joseph Fjord. It can thus be demonstrated that significant ice-stream activity and iceberg calving occurred there. Present-day iceberg production is mainly concentrated to the Scoresby Sund, but the other areas apparently represent locations of larger ice-stream activity during periods prior to the Holocene.

More generally, it can be concluded that southerly surface-water flow similar to the present East Greenland Current must also have occurred prior to the Holocene. Although either North America (Canada) or Scandinavia - or both - are generally referred to as important regions for the provenance of ice-rafted detritus, we conclude that (East) Greenland may have been an important source for (late) glacial North Atlantic ice-rafted detritus production as well.
\end{abstract}

Keywords: Denmark Strait Overflow, East Greenland Current, Greenland ice-sheet dynamics, iceberg provenance, ice-rafted detritus (IRD), Late Quaternary

\section{Introduction}

The present study is part of a project financed by the Netherlands Geoscience Foundation (GOA), which focuses on late Quaternary palaeoceanographic conditions and sedimentary processes downstream of the Denmark Strait overflow gateway. The aim of the present contribution is to present information on the provenance of coarse ice-rafted detritus (IRD) found at one site in the studied area and its implication for late Quaternary regional surface circulation off East Greenland.

The continental slope and rise off SE Greenland can be considered as a potential key area for palaeoceanographic and palaeoclimatic studies with direct relevance for western Europe, since it is located in the immediate vicinity of the Denmark Strait Arctic Gateway for watermass exchange between the Arctic and Atlantic Ocean. The seafloor morphology and information from multichannel seismic recording show the presence of numerous sediment drifts, thus providing evidence for the palaeoceanographic potential of the area. The distribution and shape of the drifts is also affected by down-slope processes transporting upper-slope/shelf sediments of mainly glacial origin. The area thus offers a unique opportunity to study the sediment drifts, with regard to both the (palaeo)oceanic flow regime and the climatically inherited signal from the down-slope sediment input.

The present-day surface hydrography of the region is characterized by southerly transport of cold surface water by the the 'East Greenland Current', whereas 
relatively warm and saline waters are transported in northerly direction towards the Denmark Strait southwest of Iceland by the 'Irminger Current' (Fig. 1). Currently, the Scoresby Sund fjord system contains the most productive fast-flowing outlet glaciers draining east from the Greenland Ice Sheet, calving $18 \mathrm{~km}^{3}$ of icebergs annually (Dowdeswell et al., 1992).

During glacial maxima, grounded ice sheets extended out to the shelf edge. Turbidity channels provide evidence for significant transport of terrigenous material to the continental rise (Johnson et al., 1975), where redeposition of sediments has been forming large elongate sediment drifts.

Seismic studies and sediment core analyses have provided a qualitative estimate of the extent and timing of seven glaciations of the continental shelf along the margin of East Greenland between $65^{\circ} \mathrm{N}$ and $70^{\circ} \mathrm{N}$ (Stein, 1992): radiocarbon dates from sediment cores indicate that the ice margin had retreated after the Last Glacial Maximum to the middle continental shelf by approx. $15 \mathrm{ka}$ before present (BP) on the outer shelf; a significant up-core decrease in accumulation rate from around $350 \mathrm{~cm} \cdot \mathrm{ka}^{-1}$ at $13-14 \mathrm{ka} \mathrm{BP}$ near the former ice margin to less than $10 \mathrm{~cm} \cdot \mathrm{ka}^{-1} \mathrm{un}$ der Holocene conditions was found. The drastic climatic change and gradual retreat of continental ice masses and sea-ice cover during the last deglaciation (Termination I) are clearly documented in the sediments by increased organic carbon and biogenic opal deposition indicative of enhanced surface-water productivity (Nam et al., 1995). Timing of the retreat of the ice margin on the southeastern Greenland shelf corresponds with the deglaciation chronology of the Canadian continental margin of Nova Scotia, where a general withdrawal of the ice occurred by $14 \mathrm{ka} \mathrm{BP}$ (Keigwin \& Jones, 1995).

Sediment ridges on the continental rise, as they appear on the sonographs, likely result from (glacial) downslope mass-flow processes, to some extent locally re-shaped by bottom currents. Video-images from the sampling site, recorded during the $1997 \mathrm{RV}$ 'Professor Logachev' Denmark Strait Expedition, show the abundant presence of large boulders in a sand and clay matrix, forming the top of one of these ridges. The grab sample $\left(1.5 \mathrm{~m}^{3}\right)$ contained abundant and varied coarse fragments, which are considered IRD and therefore key-witnesses to the provenance and pathways of the icebergs which carried them to the area of sampling. Oone should keep in mind, however, that the studied sample may contain redeposited glacigenic material, including IRD, from mass-wasting processes on the nearby upper slope or shelf, but - as shown in the present study - the vast majority of the stones must have been transported from the north

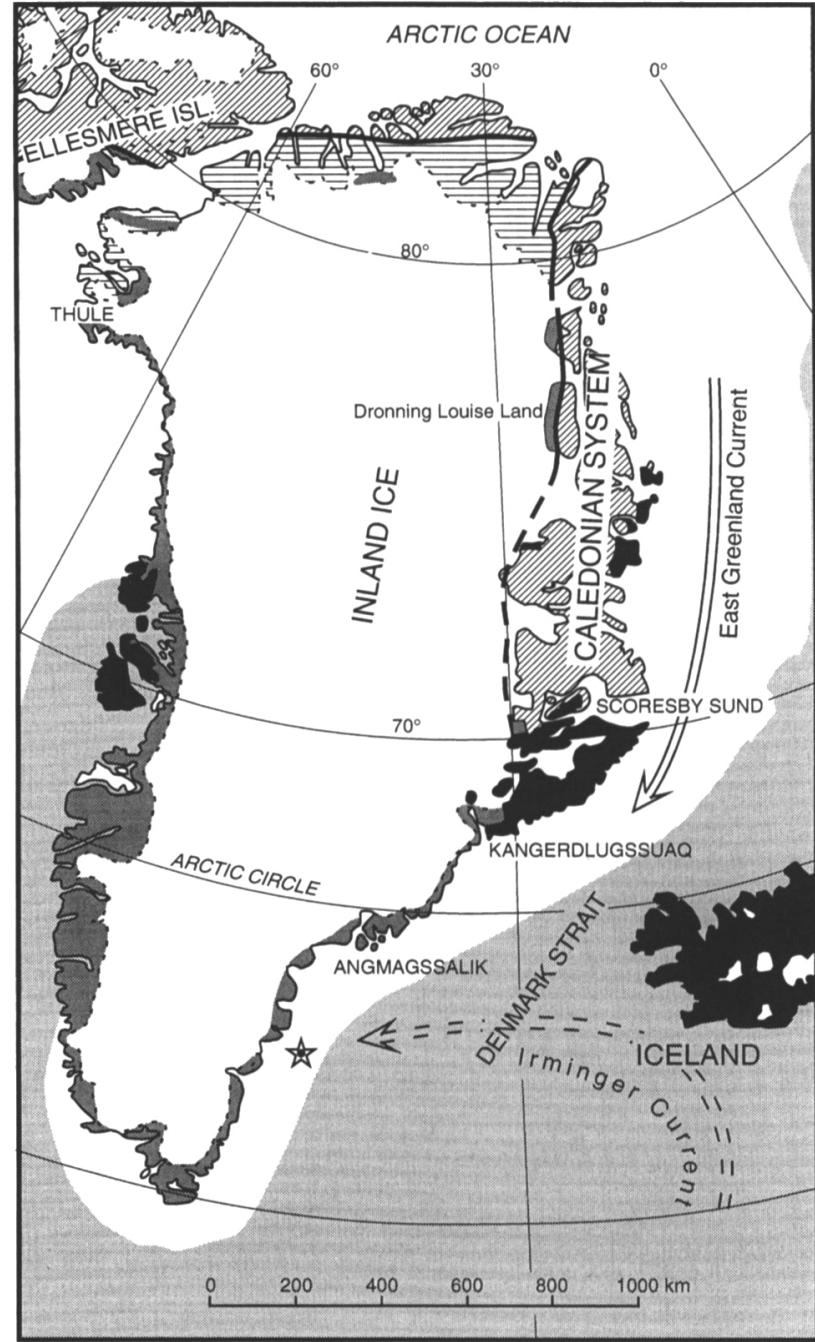

Cenozoic volcanic rocks

Palaeozoic fold belts and younger platform deposits

Palaeozoic and older platform deposits

Precambrian shield gneiss

Video-grab station DS97-18

Fig. 1. Geological sketch map of Greenland. The East Greenland and Irminger Currents, the location of video-grab station DS9718 , and the inferred minimum area of provenance of coarse icerafted detritus are indicated.

over $>700 \mathrm{~km}$, thus corroborating the notion of transport by ice rafting.

Accumulation of coarse IRD in the NorwegianGreenland Sea was investigated for roughly the last 200 ka by Goldschmidt (1995), who found peak accumulations in the East Greenland Current sector that could be dated at the Oxygen Isotope stage $2 / 1$ transition.

\section{Material and methods}

The material discussed here derives from video-grab station DS97-18 taken at $63^{\circ} 03.202^{\prime} \mathrm{N} 39^{\circ} 33.446^{\prime} \mathrm{W}$ 
near the SE Greenland margin at a waterdepth of $1256 \mathrm{~m}$ (Fig. 1).

A representative selection of coarse-sized $(\varnothing>1$ $\mathrm{cm}$ ) rock fragments was taken from the very poorlysorted grab content. This material (96 specimens) was examined macroscopically on morphological properties. Thin sections were made of 64 samples for petrographic investigation; care was taken to include a fair representation of all macroscopically distinct rock types.

\section{Morphology of the dropstones}

The retrieved rocks strongly vary in size, up to a maximum of $30 \times 18 \times 17 \mathrm{~cm}^{3}$ in DS97-18-45, a cobble of hornblende diorite (Fig. 2). Most stones display irregular shapes, in which re-entering corners and rough faces are common; they may, however, be partly bounded by smoothly worn faces. In particular the smaller fragments are well described as 'splinters'. Some fragments of basalt have flat faces meeting un- der angles of about $120^{\circ}$, suggesting an origin by columnar jointing. The cobble-sized dioritic dropstone is bounded by some rather flat, rough faces but to one side by a rounded surface, easily exfoliating in scales, suggesting an origin by spheroidal weathering. A $2-\mathrm{mm}$ thick, $2 \times 3-\mathrm{cm}$ platelet of a dark grey dolomitic sandstone has a worn face with rounded corners to one side and a flat (cleavage/joint) face at the other, cutting the rounded rims sharply. The presence of this seemingly fragile, yet unbroken, platelet suggests that there has been little or no disturbance of the dropstone matrix sediment once it had settled.

The morphological aspects displayed by the majority of the stones suggest that these, after they were detached from abraded exposures, were not modified by subsequent abrasion, as can be expected from IRD.

As shown in Figure 6, a minority of the dropstones lack the typical rough, broken faces mentioned above. Several stones of pebble size do have (sub)rounded rims and corners to all sides, which shows that they

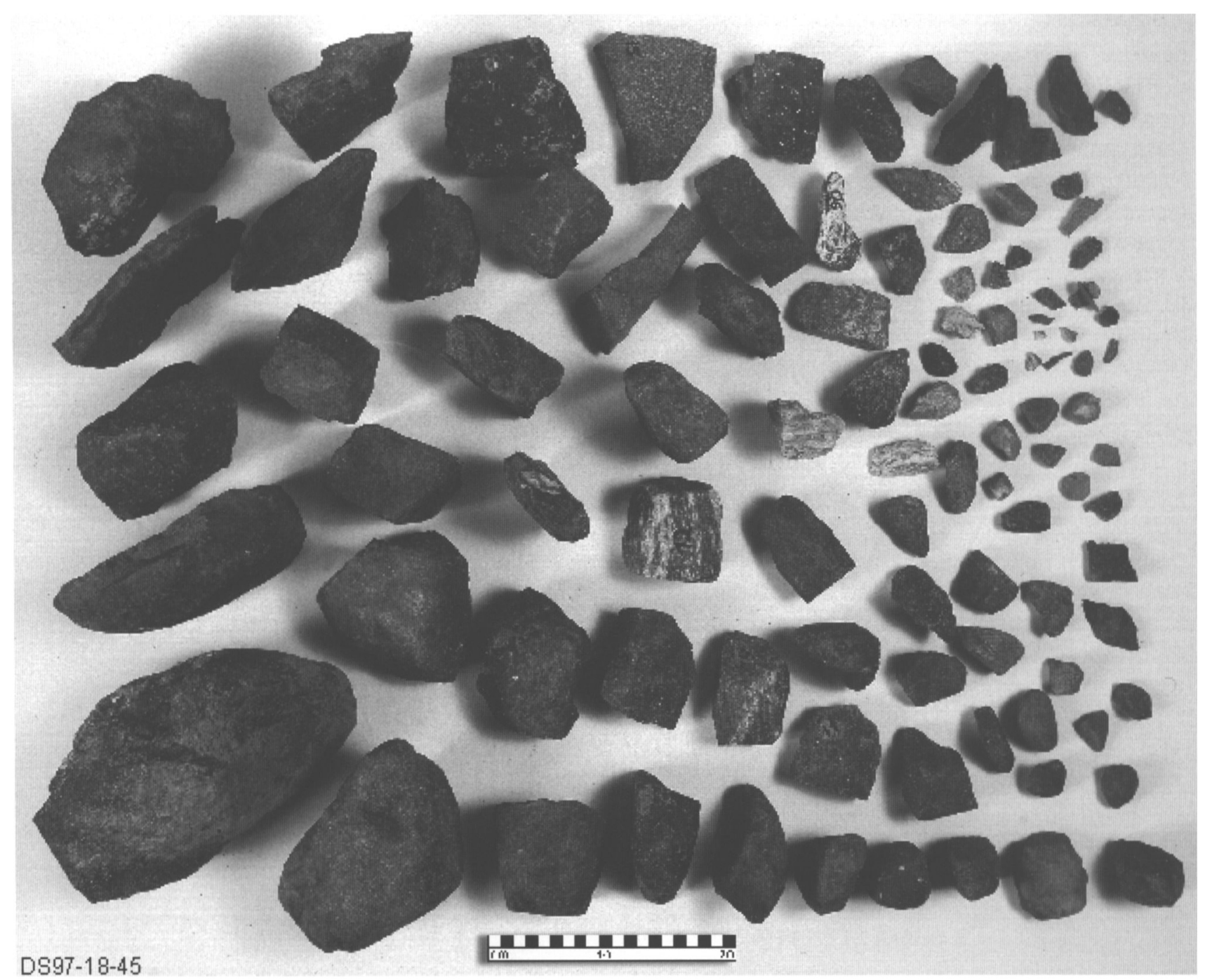

Fig. 2. The assemblage of coarse IRD sampled at video-grab station DS97-18, showing the variety in size, shape and rock type; scale bar $20 \mathrm{~cm}$. 
have undergone at least some surface transport, and may therefore have been part of a conglomerate. The perfect rounding and high degree of sphericity of three of them can only be explained by preceding histories as rolling stones. One is a typical 'Dreikanter', apparently owing its shape to an aeolian period in its history.

\section{Petrography of the dropstones}

Petrographical microscopy of thin sections of 64 samples reveals that 47 are magmatic rocks, 9 are metamorphic and 8 are sedimentary. The remaining 32 samples were determined by macroscopic observation only. In Table 1 (see also Fig. 7) the various rock types recognized in the IRD have been grouped, as a first approximation, in large categories.

\section{Magmatic rocks}

The magmatic rocks found in the sample can be grouped in two main categories: one consisting of basaltic and doleritic rocks, and a second one consisting of plutonic rocks.

\section{Basaltic and doleritic rocks (Fig. 3)}

The colour index of most samples is between about 40 and 65 . Aphyric to sub-aphyric structures prevail and about a third is porphyritic, with phenocrysts larger than $1 \mathrm{~mm}$. In an arbitrary division, based on the criterion of $0.3 \mathrm{~mm}$ for the crystal size of plagioclase in the groundmass, 26 samples are basalts, with very fine to cryptocrystalline matrices, occasionally with patches of brown glass, and 11 are dolerite, with fine-medium crystalline $(0.3-1.2 \mathrm{~mm})$ matrices. Vesicles, often filled, occur in about half of the basalts and in some dolerites.

Quenched (hollow) crystals of plagioclase in a variolitic texture set in glassy to cryptocrystalline, fragmented groundmasses (hyaloclastite), suggesting subaqueous extrusion, were found in three samples only (DS97-18-11;-13;-29).
Plagioclase is the main phenocrystic phase in 21 samples, commonly $0.5-2.5 \mathrm{~mm}$, but in three samples 3-4.5 $\mathrm{mm}$. The plagioclase phenocrysts are, as a rule, strongly zoned. The anorthite contents, approximated optically (Tobi \& Kroll, 1975), vary between $\mathrm{An}_{80}$ and $\mathrm{An}_{60}$ in the cores, to between $\mathrm{An}_{60}$ and $\mathrm{An}_{40}$ in the rims and in the groundmass crystals. Outlying values of $\mathrm{An}_{40-20}$ were found in an altered dolerite. Augite phenocrysts, occurring in twelve samples, usually are smaller $(0.5-1 \mathrm{~mm})$ and less abundant. Olivine, $\mathrm{Fo}_{70-85}$ as approximated from $2 \mathrm{~V}_{\alpha}>80^{\circ}$, occurs as partly to completely pseudomorphosed microphenocrysts in three basalts and five dolerites. Specimen DS97-1853 is a remarkably porphyritic basalt with up to $6 \mathrm{~mm}$ large phenocrysts of olivine and zoned Ti-augite; interestingly, the fresh olivine phenocrysts contain melt inclusions consisting of clinopyroxene, hornblende, plagioclase and magnetite.

The matrices of basalts and dolerites are essentially composed of plagioclase, augite and magnetite, in intergranular and subophitic textures. Subcalcic augite $\left(2 \mathrm{~V}_{\gamma} \sim 40^{\circ}\right)$ and pigeonite $\left(2 \mathrm{~V}_{\gamma}<30^{\circ}\right)$ were found occasionally. A little biotite occurs in a few samples. Opaque, platy and skeletal crystals found in some samples, may be ilmenite.

Quartz is only found interstitially in three strongly altered, amphibole-bearing 'diabasic' types (DS97$18-14 ;-16 ;-48)$.

The majority of the samples are not or only slightly altered; small quantities of brown (oxidized) celadonite, chlorite (chlorophaeite) and hematite are common alteration products and acicular actinolite is occasionally present as well. Olivine, also in otherwise little altered samples, shows various grades of pseudomorphism by either celadonite, chlorophaeite, iddingsite or bowlingite. Alteration is particularly strong in one basalt (DS97-18-26) and five less finegrained samples (DS97-18-14;-16;-21;-41;-48). In these metabasites and 'epidiorites', plagioclase is strongly clouded and sericitized or saussuritized and clinopyroxene is uralitized into brown hornblende rimmed by actinolite; chlorite and epidote are signifi-

\begin{tabular}{llllr}
\hline rock types & & $\begin{array}{l}\text { microscopic } \\
\text { determination }\end{array}$ & $\begin{array}{l}\text { macroscopic } \\
\text { determination only }\end{array}$ & total \\
\hline volcanic & (1) basalt/dolerite & 37 & 14 & 51 \\
plutonic & (2) felsic/interm. & 9 & 9 & 18 \\
& (3) mafic & 1 & 7 & 1 \\
metamorphic & (4) orthogneiss & 5 & 2 & 12 \\
\multirow{2}{*}{ sediment } & (5) metasediment & 4 & & 6 \\
\hline total & (6) various & 8 & 32 & 86 \\
\hline
\end{tabular}

Table 1. Rock types found in coarse IRD of video-grab DS97-18 (see also Fig, 3). 


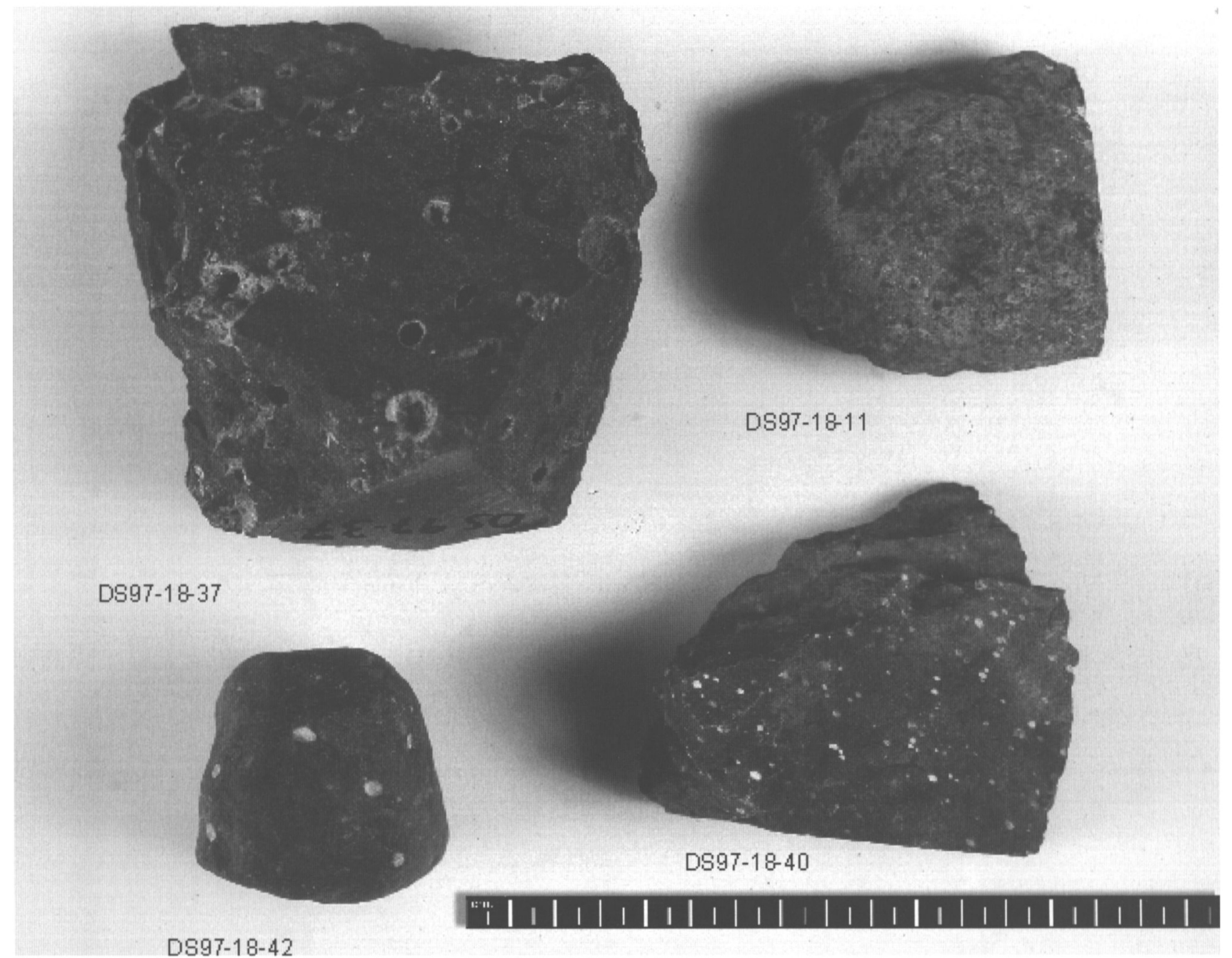

Fig. 3. Three dropstones of basalt and one of strongly altered diabase. Basalt specimen DS97-18-37 shows partly filled, cm-size vesicles; specimen DS97-18-42 has filled vesicles of $0.5 \mathrm{~cm}$; and specimen DS97-18 has a plagioclase phyric texture. The diabase DS97-18-11 shows dark, altered phenocrysts. Scale bar in $\mathrm{cm}$.

cantly present; sphene and apatite are relatively abundant. A prehnite vein was observed in the altered basalt.

As a rule, vesicles are filled, often in a zonary fashion, with various combinations of celadonite (often oxidized and brown, occasionally fresh and apple green), chlorophaeite, chlorite, actinolite, zeolite and calcite.

None of these basaltic rocks contain any feldspatoid minerals and there are no volcanic dropstones of acid and intermediate compositions.

With plagioclase as the dominant phenocryst in most samples, and feldspatoids absent in all, the bulk of the basaltic rocks can be categorized as tholeiites.

\section{Plutonic rocks}

Eight samples are medium-grained rocks, composed mainly of plagioclase, biotite and/or hornblende; Kfeldspar and quartz are present in some samples as well. Four diorites, two tonalites, a quartz-bearing monzodiorite and a plagiogranite were determined, with colour indexes varying from 35 to 10 . Plagioclase compositions in these intermediate rocks are in the andesine range; in zoned crystals of some samples, they vary from bytownite and andesine to oligoclase/albite. Augite occurs as distinct anhedral grains included in hornblende crystals in diorite specimen DS97-18-54 and as coaxially intergrown relicts in hornblende crystals in specimen DS97-18-60. Redgreen pleochroic orthopyroxene ('hypersthene') forms an additional phase in specimen DS97-18-59. Magnetite, ilmenite, titanite and apatite are common accessories. Most samples are more or less altered, with saussurite in the cores of plagioclase crystals and the mafic minerals partly replaced by actinolite and chlorite.

In addition to the intermediate rocks two remarkably different plutonic dropstones occur. The first is specimen DS97-18-07, a quartz-bearing norite, dominated by coarse-grained orthopyroxene (with exsolution lamellae), brown hornblende and further contain- 


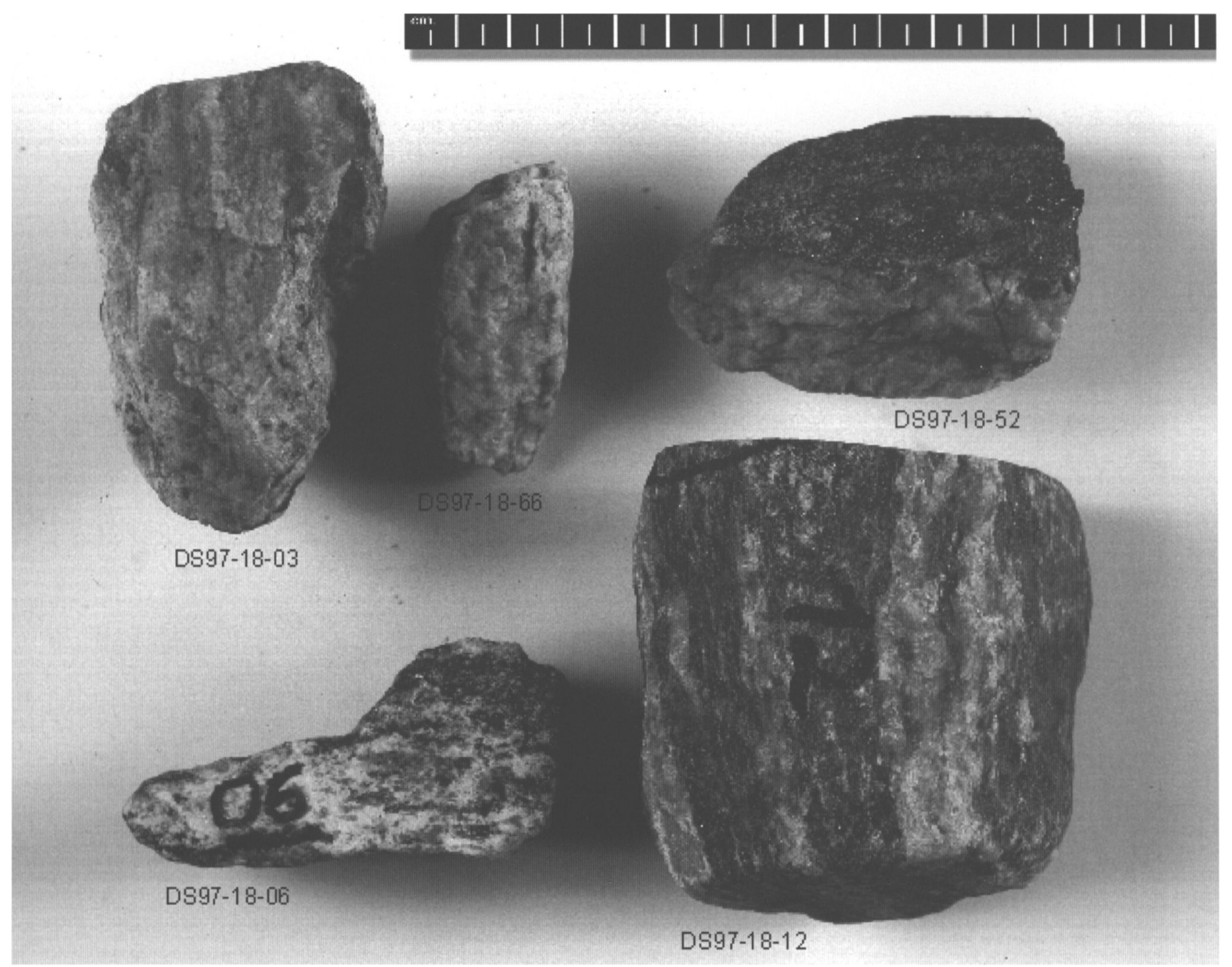

Fig. 4. Typical gneissic dropstones. Specimens DS97-18-06, -52, and -66 are orthogneisses of granodioritic composition; specimen DS97-1803 is a garnet-bearing granulite; DS97-18-12 is a kyanite-sillimanite-garnet-biotite gneiss. Scale bar in cm.

ing some plagioclase $\left(\mathrm{An}_{65}\right)$ and a little quartz; the second is specimen DS97-18-57, a quartz-alkali feldspar syenite, composed of approx. $85 \%$ mesoperthitic feldspar, approx. $10 \%$ quartz, a little myrmekitic oligoclase and, as mafic minerals, brown biotite, green biotite and pseudomorphs after fayalite formed by aggregates of bowlingite, colourless mica, carbonate and opaque material.

\section{Metamorphic rocks}

Five of the metamorphic dropstones (DS97-18-04; $06 ;-10 ;-50 ;-51)$ are granodioritic orthogneisses (Fig. 4). Their structures vary from outspoken gneissic and banded to those without banding, in which dispersed biotite and hornblende crystals have a more or less preferred orientation. As a rule, the amphibole is a common green hornblende, but ferrohastingite $\left(2 \mathrm{~V}_{\alpha} \sim 40^{\circ}\right.$; pleochroic blue and green) is present in specimen DS97-18-04. Most of these gneisses are only slightly modified by retrogradation. The feldspar of a gneissic band in specimen DS97-18-06, however, is heavily clouded and biotite features strong chloritization and lenses of prehnite.

Specimen DS97-18-12 is a mortarized kyanite-sillimanite-garnet-biotite gneiss, a metapelite; DS97-1803 is a rutile-bearing garnet granulite rich in perthitic feldspar and lensoid quartz; DS97-18-55 is a feldspathic quartzite with well-rounded zircon grains and patches of carbonate, probably a meta-arkose; DS97$18-56$ is a sillimanite-bearing quartz muscovite phyllite with cloritized biotite porphyroblasts and numerous needles of sillimanite included in the quartz crystals. Abundant rounded zircon grains attest to a sedimentary protolite.

By macroscopic observation only, there are another seven orthogneisses and two more coarse-grained biotite schists.

\section{Sediment-derived rocks}

Well-rounded stones are considered as dropstones de- 


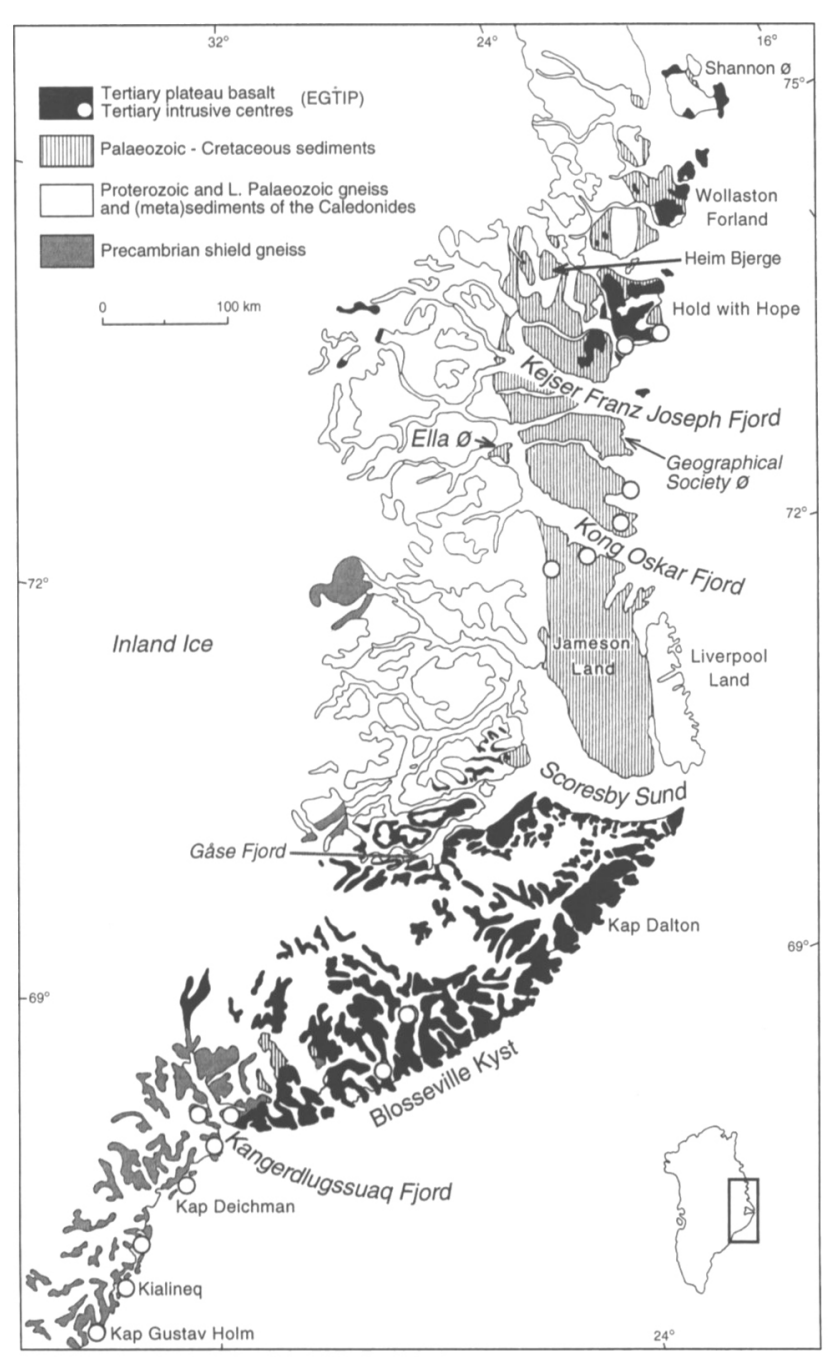

Fig. 5. Geological sketch map of East Greenland with topographical names mentioned in the text and in Figure 4. EGTIP = East Greenland Tertiary Igneous Province.

rived from pebble-bearing sedimentary deposits. In this sense, specimen DS97-18-61 - a perfectly rounded, $3 \times 4 \times 5 \mathrm{~cm}^{3}$, stone of ophitic olivine dolerite - was once a pebble in a conglomerate. Specimen DS9718-64 is a well-rounded pebble of recrystallized quartzite; specimen DS97-18-58 is a $1.5 \times 2 \times 2 \mathrm{~cm}^{3}$, well-rounded pebble of very fine-grained calcarenite with scattered angular to sub-angular grains of quartz and feldspar; cross lamination is marked by arkosic streaks. The sub-rounded fragment DS97-18-63, a grey fine-grained limestone, is also considered of conglomeratic derivation. Two granitic dropstones and one grey quartzite, with largest dimensions between 2 and $3 \mathrm{~cm}$, are rounded on the edges and are therefore also seen as former pebbles of conglomeratic deposits.

Specimen DS97-18-02 is a ventifact of red quartz arenite, showing fine sedimentary layering, composed of very well-sorted and well-rounded quartz grains set in a quartz cement; specimen DS97-18-19 is a lime- stone containing Palaeozoic brachiopods and gastropods (Boekschoten, oral comm., 1999). Specimen DS97-18-28 is a lump of sandstone of $7 \times 13 \times 22 \mathrm{~cm}^{3}$, bounded by a roundish, former abrasion surface and by broken faces. The grey and locally rusty rock is a lithic subarkose, composed essentially of well-sorted but angular and subrounded grains with a low sphericity and subordinate well-rounded, highsphericity grains. The grains $(0.3 \mathrm{~mm})$ of quartz, unaltered plagioclase and $\mathrm{K}$-feldspar with irregularly shaped opaque material and scattered muscovite flakes are set in cement of carbonate. Tourmaline and broken fragments of rounded zircon crystals are accessories. Specimen DS97-18-62 is a $0.2 \times 2 \times 3 \mathrm{~cm}^{3}$ platelet with well-rounded rims of dark grey dolomite.

\section{Discussion: possible terrains of provenance}

The substantial presence among the studied dropstones of gneisses, granulite and metapelitic metamorphic rocks, and siliciclastic sediments indicates continental basement as a terrain of provenance per se, and, by consequence, East Greenland. For excellent reviews of the geology of the geology of this region, the reader is referred to Haller (1971) and articles in Escher \& Watt (1976). In Figures 1 and 5, the broad outlines of the geology of East Greenland are given, as well as the topographical names used in the following.

Greenland, as part of the Precambrian shield area of North America, is largely built up by high-grade gneissic rocks. In the northern half of East Greenland, the old crystalline block is rimmed by a Caledonian fold belt, comprising orthogneisses, paragneisses and schists, Neoproterozoic to Early Palaeozoic sediments and various types of intrusive rocks. Devonian to Early Permian continental platform deposits, covering the folded units unconformably as a Caledonian molasse, are followed by Late Permian and Mesozoic, dominantly marine, sediments. Between $68^{\circ} \mathrm{N}$ and $75^{\circ} \mathrm{E} 20^{\prime} \mathrm{N}$, a variety of magmatic rocks belonging to the East Greenland Tertiary Igneous Province (EGTIP) occur.

It can be appreciated from the above outline that East Greenland offers a wide variety of rock types. Indeed, the full variation of the dropstone lithologies can be traced to rock units exposed in East Greenland, to the north of the grab site.

Some basaltic IRD contribution from Iceland, contingently having arrived by means of icebergs crossing the Denmark Strait via the Irminger Current (Fig. 1), should, however, be considered as well. Apart from superficial (mainly glacial) deposits, Iceland consists entirely of late Tertiary and Quaternary volcanic and 
related intrusive rocks. The volcanic rocks are predominantly (80-85\%) subaerial flood basalts of tholeiitic composition (Hall, 1996). It is unfortunate that a clear-cut petrographic distinction between tholeiites of continental flood basalts - as on E Greenland - and of P-type MORB from elevated ridge segments - as on Iceland - cannot be readily made (Wilson, 1989). Consequently, Iceland cannot be entirely discarded as an additional source area for part of our basaltic dropstones. On the other hand, if icebergs from Iceland did play a role, one would expect to find also volcanic dropstones of intermediate to acid composition, which make up $10 \%$ on Iceland. None of the latter types were, however, found among our dropstones. Moreover, pyroclastic and hyaloclastic basalts, locally abundant on Iceland (Hall, 1996), are very rare as IRD. Consequently, contribution to the studied grab sample from Iceland, if any, can be considered very subordinate.

\section{Provenance of the magmatic IRD}

The dominance $(53 \%)$ of tholeiitic basalts and dolerites in the dropstone population under study points to a tholeiitic volcanic hinterland as a major source area. EGTIP, the western part of the North Atlantic Igneous Province associated with the opening of the North Atlantic Ocean (65-50 Ma), is such a domain (Fig. 1). EGTIP rocks occur over a distance of approx. $1200 \mathrm{~km}$, from Kap Gustav Holm to Shannon $\varnothing$ (Fig. 5), and comprise continental flood basalts, dyke complexes, dolerite sills, layered gabbro complexes, syenite-granite plutons and various central complexes (Deer, 1976; Noe-Nygaard, 1976; Nielsen, 1987; Larsen et al., 1989). The late Proterozoic Zig-Zag Dal Basalt Formation of eastern North Greenland is a remnant of another tholeiitic province (Kalsbeek \& Jepsen, 1984), but is discarded here as its lavas have been strongly spilitized, which is not generally observed in the dropstone basalts.

\section{Basalts and dolerites}

EGTIP lavas are continuously exposed $\mathrm{km}$ in a 300$\mathrm{km}$ long coastal segment between the Kangerdlugssuaq Fjord $\left(68^{\circ} \mathrm{N}\right)$ and the Scoresby Sund $\left(70^{\circ} 30^{\prime} \mathrm{N}\right)$, extending some $200 \mathrm{~km}$ inland from the Blosseville Kyst. The lavas of this plateau, with an area of approx. $65,000 \mathrm{~km}^{2}$, attain a thickness of more than $5.5 \mathrm{~km}$ in the central coastal areas but thin inland to $2-3 \mathrm{~km}$ (Pedersen et al., 1997). Basaltic outliers, dissected relicts of a formerly continuous lava plateau (originally $\sim 16,000 \mathrm{~km}^{2}$ and $\sim 1.5 \mathrm{~km}$ thick) are exposed some $400 \mathrm{~km}$ further north in an approx. $50-\mathrm{km}$ wide zone of islands and peninsulas between
Kejser Franz Joseph Fjord and Shannon Ø (Upton et al., 1980, 1984). Separate from this plateau, venterupted alkaline, feldspatoid-bearing lavas occur in nunataks $200 \mathrm{~km}$ inland at $74^{\circ} \mathrm{N}$ (Noe-Nygaard, 1976). The latter can be left alone as such rock types are not found as dropstones. Tertiary sills and dykes further occur in a coastal zone between the plateaus, from the Scoresby Sund to the Kejser Franz Joseph Fjord $\left(70-75^{\circ}\right)$.

The petrographies of the vast majority of the basaltic and doleritic dropstones comply in structural and mineralogical details with the descriptions in the literature of the dominant lavas and the associated sills and dykes of the Blosseville Plateau (Brooks et al., 1976; Deer, 1976; Nielsen, 1978; Larsen \& Watt, 1985; Hogg et al., 1989; Larsen et al., 1989; Pedersen et al., 1997); the scarcety of dropstones with quenching textures (specimens DS97-18-11;-13;-29) and the single dropstone of aberrant olivine and $\mathrm{Ti}$-augite phyric 'ankaramitic' lava (DS97-18-53) is in line with their rare and smaller areas of exposure (Brooks et al., 1976; Gill et al., 1988; Larsen et al., 1989; Brown et al., 1996; Fram \& Lesher, 1997). Some of the strongly altered, quartz-bearing 'diabase' dropstones, however, may be derived from Old Red (Devonian) intrusives, as exposed between $73^{\circ}$ and $73^{\circ} 45^{\prime} \mathrm{N}$, near the Kejser Franz Joseph Fjord (Haller, 1971). Some additional supply from dykes, sills and lavas of the northern plateau (Noe-Nygaard, 1976; Upton et al., 1980) cannot be excluded, although a major role as a hinterland is unlikely. If that were the case, more of the quartz-bearing and andesitic types, dominating the Lower Plateau Lava Series of the northern plateau, as well as the sills and dykes of that region (Upton et al. $1980,1984)$, would be expected as dropstones. In contrast, apart from three strongly altered 'diabases' (here interpreted as Devonian) which do contain some quartz, none of the basaltic and doleritic dropstones are quartz-bearing, nor are there andesitic dropstones. Also, the following conflicting mineralogical details (Upton et al. 1984) are not supporting a provenance of the tholeiitic dropstones from this northern region. Feldspatoid minerals, relatively common in the Upper Plateau Lava Series of Hold with Hope, are not present in the dropstones. Biotite, a common groundmass phase in the Upper Plateau Lava Series, is scarcely present in some basaltic dropstones only. Rocks of the Upper Plateau Lava Series, typically biotite-free, and in that respect comparable with the southern tholeiites, can be discriminated on account of their olivine phenocrysts, which have Fo $<67$, in contrast to Fo $>70$ found in olivine from dropstones and in lavas of the Blosseville Plateau. Finally, Mesozoic sedimentary rocks, as reefal lime- 
stones, evaporites and gypsiferous shales (Birkelund \& Perch-Nielsen, 1976), closely associated, as country rock of the northern basaltic province (Haller, 1971), have not been found among the dropstones.

\section{Plutonic rocks}

Apart from dioritic xenoliths in a Tertiary granitesyenite intrusion near $67^{\circ} \mathrm{N}$ (Myers, 1980), granodioritic to dioritic intrusions have not been reported from EGTIP (Nielsen 1987; Brooks \& Nielsen, 1982). Apparently, a provenance of the eight dropstones from Tertiary exposures of plutonic rocks of monzodioritic to tonalitic/plagiogranitic and dioritic composition is highly improbable. These plutonic rocks of intermediate compositions were derived either from plutons in the Precambrian basement, or rather from the Caledonian system, where such intrusive bodies are plentiful in the central zone between $70^{\circ}$ and $71^{\circ} 30^{\prime} \mathrm{N}$, and on Liverpool Land.

The quartz-bearing norite (specimen DS97-18-07) matches strikingly well Deer's (1976) description of a peculiar coarse-grained rock from a Tertiary macrodyke near the mouth of Kangerdlugssuaq Fiord $\left(68^{\circ} \mathrm{N}\right)$, containing hornblende, augite, orthopyroxene with exsolved clinopyroxene, labradorite and some quartz-alkalifeldspar mesostasis.

The fayalite-bearing quartz alkalisyenite (specimen DS97-18-57) is particularly similar to those described by, respectively, Brown et al. (1977) and Deer (1976) from EGTIP plutonic centres at Kialineq $\left(67^{\circ} \mathrm{N}\right)$ and Kap Deichman $\left(68^{\circ} \mathrm{N}\right)$.

\section{Provenance of the metamorphic IRD}

Orthogneisses of granodioritic to tonalitic composition are the dominating rock types in the Precambrian shield as well as in the, reworked, basement gneiss complexes of the Caledonian structural units. These high-grade gneisses, with local evidence of granulite facies (Henriksen \& Higgins, 1976; Henriksen, 1985; Higgins, 1988; Kalsbeek et al., 1993a,b; Kalsbeek, 1995), are exposed in the shield, continuously along the southeastern coast up to the Kangerdlugssuaq Fjord $\left(68^{\circ} 30^{\prime} \mathrm{N}\right)$ and further north in a narrow zone landinward from the Blosseville Kyst, disappearing under the inland ice; in the foreland and basement complexes of the Caledonides, they occur throughout most of the length of the belt. Additional outcrops are found at Liverpool Land, a coastal peninsula between $70^{\circ} 30^{\prime}$ and $71^{\circ} 30^{\prime} \mathrm{N}$, in a horst-like structure outlying from the main exposures of gneiss.

Apparently, the five biotite-hornblende orthogneiss dropstones (specimens DS97-18-04;- 06; -10; -50; 51) and the granulite dropstone (specimen DS97-18-
03) are not very useful for indicating some restricted area of provenance. Their sources may lie at almost any latitude along the coast or Inland Ice line of East Greenland north of the grab site.

Sources for the medium- to high-grade metasedimentary dropstones, including the kyanite-bearing paragneiss (specimens DS97-18-08; -12;-56) are of more restricted occurrence. Possible sources are the Krummedal and Smallefjord supracrustal successions, widely exposed in the inland fjord zone, from $70^{\circ}-74^{\circ} \mathrm{N}$, and in a more coastal zone from $73^{\circ} 30^{\prime}-$ $76^{\circ} \mathrm{N}$, respectively (Higgins et al., 1981; Higgins, 1988; Friderichsen et al., 1994); the metamorphic basal parts of the Neoproterozoic Eleonore Bay Group, exposed between $70^{\circ}$ and $76^{\circ} \mathrm{N}$ (Henriksen, 1985; Caby \& Bertrand-Sarfati, 1988); an area north of Angmakssalik $\left(66^{\circ} \mathrm{N}\right)$ in the Precambrian shield (Bridgewater et al., 1976; Kalsbeek et al., 1993b); and Liverpool Land, at approx. $70^{\circ} 30^{\prime}$ and $71^{\circ} 30^{\prime} \mathrm{N}$ (Henriksen \& Higgins, 1976).

\section{Provenance of IRD with a sedimentary origin}

Sedimentary deposits of East Greenland are widely exposed in the Caledonian realm and adjoining areas extending from $70^{\circ}$ to $82^{\circ} \mathrm{N}$; in addition, exposures of Cretaceous and earliest Tertiary sediments occur north of Kangerdlugssuaq and local Eocene deposits cover the Blosseville plateau (Haller, 1971; Birkelund \& Perch-Nielsen, 1976; Dawes, 1976; Henriksen \& Higgins, 1976; Soper et al., 1976a,b). Several of the stones, regardless their lithology, can be argued to have been derived from sedimentary formations because of their more or less well-rounded shapes (Fig. 6). These various 'pebbly' dropstones may have been transported from almost any of the many conglomeratic deposits, occurring throughout the stratigraphies of $\mathrm{E}$ and NE Greenland, ranging in age from Precambrium to fluviatile/beach deposits of Quaternary interglacials.

Specimen DS97-18-61, the well-rounded pebble of olivine dolerite, if not from some Quaternary river or beach deposit, may be derived from an exposure at Savoia Halvø, at the northeastern end of the Blosseville Kyst Plateau, where an Eocene conglomerate comprises well-rounded pebbles of tholeiitic rocks (Larsen et al., 1989).

The hinterland of DS97-18-19, the limestone with Palaeozoic brachiopods and gastropods, must be restrained to exposures of the Lower Ordovician, which form a narrow zone in the central fjord zone, from Ella $\varnothing$ to Heim Bjerge, between $72^{\circ} 50^{\prime}$ and $74^{\circ} \mathrm{N}$ (Henriksen \& Higgins, 1976).

Grey sandstones are found abundantly in the Neo- 


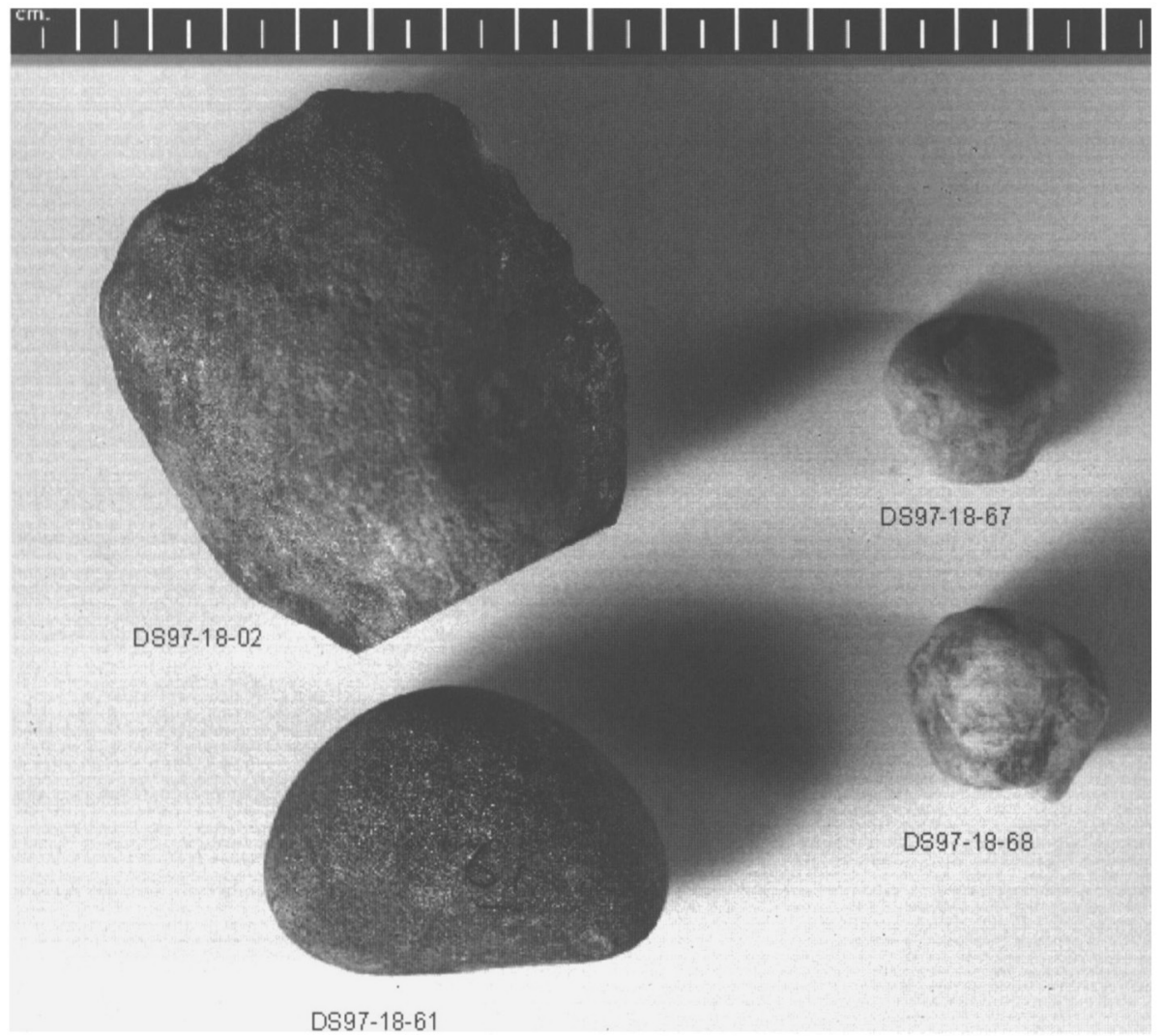

Fig. 6. Well-rounded pebble of dolerite (specimen DS97-18-61), sub-rounded pebbles of quartzite (specimen DS97. 18-67) and granite (specimen DS9718-68), and a ventifact ('Dreikanter') of quartzitic arenite (specimen DS97-1802 , cut at one end for a thin section). Scale bar in $\mathrm{cm}$.

proterozoic Eleonore Bay Group and also in the Devonian to Late Permian deposits (Haller, 1971; Henriksen, 1985), which have been named, respectively, 'Grenvillian grey molasse' (Caby \& Bertrand-Sarfati, 1988) and 'Caledonian molasse' (Haller, 1971). For the grey lithic subarkose dropstone (specimen DS97$18-28)$, the 'Caledonian molasse' $\left(71^{\circ} 20^{\prime}-74^{\circ} 30^{\prime} \mathrm{N}\right)$ can be considered the more likely source, as the rock is not as strongly lithified as can be expected from rocks of the Eleonore Bay Group.

Specimen DS97-18-02, the red quartzitic ventifact poses a problem in itself, as the literature does not specifically mention the occurrence of ventifacts in East Greenland; only Birkelund \& Perch-Nielsen (1976: 316) report the finding of 'wind-polished' pebbles in the Early Triassic Paradigmabjerg Member, which is well developed in the northern parts of Jameson Land, south of $72^{\circ} \mathrm{N}$. Conditions for the shaping of ventifacts may, however, have prevailed several times in the geological history of East Greenland. Continental intervals are documented in the cover of the crystalline basement for the Late Precambrian, and also during the formation of the 'Grenvillian and Caledonian molasses'. It is remarkable in this respect that wind-polished and faceted pebbles (ventifacts) occur in the basal parts of the Torridonian Sandstone, the Neoproterozoic sedimentary cover of the Precambrian basement of Lewisian Gneiss in the Caledonian foreland of NW Scotland (Barber \& Soper, 1973;
Stewart, 1978), i.e. in a quite similar setting as the Caledonian foreland of East Greenland. The more so, as the crystalline basement of northern Scotland - the Lewisian complex - is very similar to the Nagssugtoqidian mobile belt of the Archaean Craton of East Greenland (Myers, 1987; Kalsbeek et al., 1993b). Also, palinspastic reconstructions of the Caledonidian fold belt in a pre-Atlantic drift configuration show the Caledonian front of Scotland as a southern prolongation in East Greenland (Higgins, 1988; Winchester, 1988; Kalsbeek, 1995). The type succession of the Precambrian sedimentary cover of the crystalline rocks in the Caledonian foreland was named the 'Trekant Series' by Peacock (1956), after the typical trianular shape of nunatak Trekanten (Danish for 'Dreikant'), but what's in a name?

\section{Conclusions}

The following five main conclusions can be drawn from the above data and considerations.

Rock types found as dropstones at video-grab station DS97-18 at $63^{\circ} 03.202^{\prime} \mathrm{N} 39^{\circ} 33.446^{\prime} \mathrm{W}$ near the SW Greenland margin at a waterdepth of $1256 \mathrm{~m}$ can all be allocated to geological formations of East Greenland (Fig. 7).

The minimal extension of the accumulated areas of provenance stretches from about $73^{\circ} \mathrm{N}$ to $68^{\circ} \mathrm{N}$ (Fig. 7). The northern limit is indicated by Ella $\varnothing$ and the 


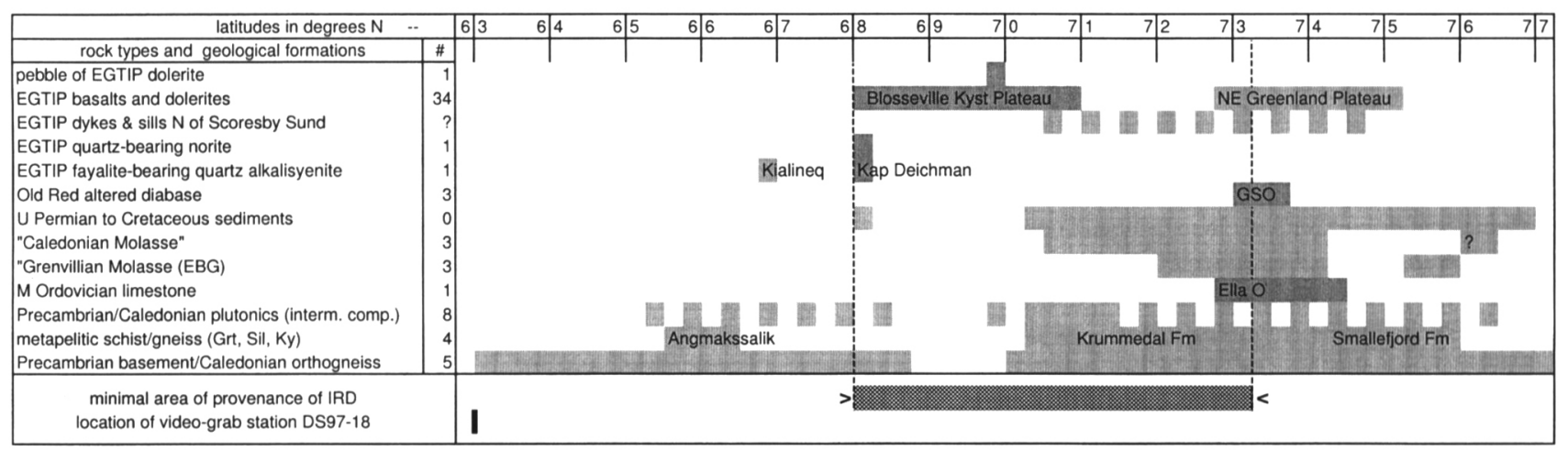

Fig. 7. Schematic distributions, in terms of latitudes, of outcrop of rock formations and rock types outcropping in eastern Greenland, on the basis of literature cited in the text. Extensions of outcrops of rock types that are important for constraining the southern and northern limit of the minimal total area of provenance are highlighted in darker shades. The column indicated by \# gives the numbers of microscopically identified dropstones as these are allocated to the various formations. Ella $O=$ Ella $\emptyset$, GSO $=$ Geographical Society $\emptyset$.

southern borders of Kejser Franz Joseph Fjord (Fig. 5), with the southernmost occurrences of Early Ordovician limestones with brachiopods and gastropods and of Old Red (Devonian) altered 'diabases', respectively. The southern limit is at Kap Deichman, where fayalite-bearing quartz alkalisyenite is exposed. All other rock types found as dropstones are exposed between these limits.

The provenance of all dropstones could be explained by transport from areas attributing to the Kangerdlugssuaq Fjord, small fjords along the Blosseville Kyst, the Scoresby Fjord, the Kong Oskar Fjord and the Kejser Franz Joseph Fjord.

Contribution from more southern and northern parts of East Greenland can, however, not be excluded. Orthogneisses similar to those found as dropstones occur at many locations spread along the entire eastern and northeastern coastal areas of Greenland, for which reason dropstones of this rock type cannot constrain the area of provenance.

Considering the preponderance of basaltic/doleritic IRD $(\geq 50 \%)$ andthe importance of Caledonian plutonics ( $\geq 16 \%)$, it is concluded that contributions via the Blosseville Kyst and the Scoresby Fjord area were most important. During late Pleistocene episodes, these areas must have been characterised by significant ice discharge and iceberg production. In addition, the regional ice-stream conditions must have been different from those of today, as significant iceberg production takes place currently in the Scoresby Fjord area only. Moreover, we can conclude that, similar as today, a southerly surface current (the 'East Greenland Current') existed during these episodes.

\section{Acknowledgements}

We gratefully acknowledge the Netherlands Geoscience Foundation (GOA) for financing of the field- work. Additional support was provided by GEUS. Master and crew of RV Prof. Logachev and RV Dana are thanked for excellent cooperation. Successful coring would not have been possible without the skilful technical assistance of Jack Schilling and Leon Wuis (Netherlands Institute for Sea Research). Cooperation with the Danish Lithosphere Centre, Copenhagen, and during the work at sea in particular with John R. Hopper, Chief Scientist onboard RV Dana, is highly appreciated. Jasper Konter helped with the petrography of the thin sections.

This is contribution NSG 20000201 of the Netherlands School of Sedimentology.

\section{References}

Barber, A.J. \& Soper, N.J., 1973. Summer field meeting in the north-west of Scotland 11-18 September 1971- Proceedings of the Geological Association 84: 207-235.

Birkelund, T. \& Perch-Nielsen, K., 1976. Late Palacozoic - Mesozoic evolution of central East Greenland. In: Escher, E. \& Watt, W.S. (eds.): Geology of Greenland - Geological Survey of Greenland (København): 304-339.

Bridgewater, D., Keto, L., McGregor, V.R. \& Myers, J.S., 1976. Archean gneiss complex of Greenland. In: Escher, E. \& Watt, W.S. (eds.): Geology of Greenland - Geological Survey of Greenland (København): 18-75.

Brooks, C.K., Nielsen, T.F.D. \& Petersen, T.S., 1976. The Blosseville Coast basalts of East Greenland: their occurrence, composition and temporal variations - Contributions to Mineralogy and Petrology 58: 279-292.

Brooks, C.K. \& Nielsen, T.F.D., 1982. The E Greenland continental margin: a transition between oceanic and continental magmatism - Journal of the Geological Society (London) 139: 265-275.

Brown, P.E., Van Breeman, O., Noble, R.H. \& Macyntire, R.M., 1977. Mid-Tertiary igneous activity in East Greenland: the Kialinec complex - Contributions to Mineralogy and Petrology 64: 109-122.

Brown, P.E., Evans, I.B. \& Becker, S.M., 1996. The Prince of Wales Formation B post-flood basalt alkali volcanism in the Tertiary of East Greenland - Contributions to Mineralogy and Petrology 123: 424-434. 
Caby, R. \& Bertrand-Sarfati, J., 1988. The Eleonore Bay Group (central East Greenland). In: Winchester, J.A. (ed.): Later Proterozoic stratigraphy of the northern Atlantic regions - Blackie (Glasgow): 213-236.

Dawes, P.R., 1976. Precambrian to Tertiary of northern Greenland. In: Escher, E. \& Watt, W.S. (eds.): Geology of Greenland Geological Survey of Greenland (København): 248-303.

Deer, W.A., 1976. Tertiary igneous rocks between Scoresby Sund and Kap Gustav Holm, East Greenland. In: Escher, E. \& Watt, W.S. (eds.): Geology of Greenland - Geological Survey of Greenland (København): 405-429.

Dowdeswell, J.A., Whittington, R.J. \& Hodgkins, R., 1992. The sizes, frequencies, and freeboards of East Greenland icebergs observed using ship radar and sextant - Journal of Geophysical Research 97 (C3): 3515-3528.

Escher, E. \& W.S. Watt (eds.), 1976. Geology of Greenland - Geological Survey of Greenland (København): 603 pp.

Fram, M.S. \& Lesher, C.E., 1997. Generation and polybaric differentiation of East Greenland Early Tertiary flood basalts - Journal of Petrology 38: 231-275.

Friderichsen, J.D., Henriksen, N. \& Strachan, R.A., 1994. Basement-cover relationships and regional structure in the Grandjean Fjord-Bessel Fjord region $\left(75^{\circ}-76^{\circ} \mathrm{N}\right)$, North-East Greenland - Rapport Grønlands Geologiske Undersøgelse 162: 17-33.

Gill, R.C.O., Nielsen, T.F.D., Brooks, C.K. \& Ingram, G.A., 1988. Tertiary volcanism in the Kangerdlugssuaq region, E. Greenland: trace-element geochemistry of the Lower Basalts and tholeiitic dyke swarms. In: Morton, A.C. \& Parson, L.M. (eds.): Early Tertiary volcanism and the opening of the NE Atlantic Geological Society Special Publication 39: 161-179.

Goldschmidt, P.M., 1995. Accumulation rates of coarse-grained terrigenous sediment in the Norwegian-Greenland Sea: signals of continental glaciation - Marine Geology 128: 137-151.

Hall, A., 1996. Igneous petrology ( $2^{\text {nd }}$ ed.) - Longman Group Ltd (Essex): xiv $+551 \mathrm{pp}$.

Haller, J., 1971. Geology of the East Greenland Caledonides - Wiley Interscience (London): xxiii $+413 \mathrm{pp}$.

Henriksen, N., 1985. The Caledonides of central East Greenland $70^{\circ}-76^{\circ}$ N. In: Gee, D.G. \& Sturt, B.A. (eds.): The Caledonide orogen - Scandinavia and related areas - Wiley (London): 10951113.

Henriksen, N. \& Higgins, A.K., 1976. East Greenland Caledonian fold belt. In: Escher, E. \& Watt, W.S. (eds.): Geology of Greenland - Geological Survey of Greenland (København): 182-246.

Higgins, A.K., 1988. The Krummedal supracrustal sequence in East Greenland. In: Winchester, J.A. (ed.): Later Proterozoic stratigraphy of the northern Atlantic regions - Blackie (Glasgow): 86-96.

Higgins, A.K., Friderichsen, J.D. \& Thyrsted, T., 1981. Precambrian metamorphic complexes in East Greenland Caledonides $\left(72^{\circ} 74^{\circ} \mathrm{N}\right)$ - their relationships to the Eleonore Bay Group, and Caledonian orogenesis - Rapport Grønlands Geologiske Undersøgelse 104: 5-46.

Hogg, A.J., Fawcett, J.J., Gittins, J. \& Gorton, M.P., 1989. Cyclical variation in composition in continental tholeiites of East Greenland - Canadian Journal of Earth Sciences 26: 534-543.

Johnson, G.L., Sommerhof, G. \& Egloff, J., 1975. Structure and morphology of the West Reykjanes basin and the southeast Greenland continental margin - Marine Geology 18: 175-196.

Kalsbeek, F., 1995. Geochemisry, tectonic setting, and poly-orogenic history of Palaeoproterozoic basement rocks from the Caledonian fold belt of North-East Greenland - Precambrian Research 72: 301-315.

Kalsbeek, F. \& Jepsen, H., 1984. The late Proterozoic Zig-Zag Dal
Basalt Formation of eastern North Greenland - Journal of Petrology 25: 644-664.

Kalsbeek, F., Nutman, A.P. \& Taylor, P.N., 1993a. Palaeoproterozoic basement province in the Caledonian fold belt of NorthEast Greenland - Precambrian Research 63: 163-178.

Kalsbeek, F., Austrheim, H., Bridgwater, D., Hansen, B.T., Pedersen, S. \& Taylor, P.N., 1993b. Geochronology of Archaean and Proterozoic events in the Ammassalik area, South-East Greenland, and comparisons with the Lewisian of Scotland and the Nagssugtoqidian of Weast Greenland - Precambrian Research 62: 239-270.

Keigwin, L.D. \& Jones, G.A., 1995. The marine record of deglaciation from the continental margin off Nova Scotia - Paleoceanography 10: 973-985.

Larsen, L.M. \& Watt, W.S., 1985. Episodic volcanism during breakup of the North Atlantic: evidence from the East Greenland plateau basalts - Earth and Planetary Science Letters 73: 105116.

Larsen, L.M., Watt, W.S. \& Watt, M., 1989. Geology and petrology of the Lower Tertiary plateau basalts of the Scoresby Sund region, East Greenland - Geological Survey of Greenland Bulletin 157: 1-164.

Myers, J.S., 1980. Structure of the coastal dyke swarm and associated plutonic intrusions of East Greenland - Earth and Planetary Science Letters 46: 407-418.

Myers, J.S., 1987. The East Greenland Nagssugtoqidian mobile belt compared with the Lewisian complex. In: Park, R.G. \& Tarney, J. (eds.): Evolution of the Lewisian and comparable Precambrian high grade terrains - Geological Society Special Publication 27: 235-246.

Nam, S.-I., Stein, R., Grobe, H. \& Hubberten, H., 1995. Late Quaternary glacial-interglacial changes in sediment composition at the East Greenland continental margin and their palaeoceanographic implications - Marine Geology 122: 243-262.

Nielsen, T.F.D., 1978. The Tertiary dike swarm of the Kangerdlugssuaq area, East Greenland. An example of magmatic development during continental break-up - Contributions to Mineralogy and Petrology 67: 63-78.

Nielsen, T.F.D., 1987. Tertiary alkaline magmatism in East Greenland: a review. $I n$ : Fitton, J.G. \& Upton, B.G.J. (eds.): Alkaline igneous rocks - Geological Society Special Publication 30: 489515.

Noe-Nygaard, A., 1976. Tertiary igneous rocks between Shannon and Scoresby Sund, East Greenland. In: Escher, E. \& Watt, W.S. (eds.): Geology of Greenland - Geological Survey of Greenland (København): 386-402.

Peacock, J.D., 1956. The geology of Dronning Louise Land N.E. Greenland - Meddellinger Grønland 137 (7): 38 pp.

Pedersen, A.K., Watt, M., Watt, W.S. \& Larsen, L.M., 1997. Structure and stratigraphy of the Early Tertiary basalts of the Blosseville Kyst, East Greenland - Journal of the Geological Society (London) 154: 565-570.

Soper, N.J., Downie, C., Higgins, A.C. \& Costa, L.I., 1976a. Biostratigraphic ages of Tertiary basalts on the East Greenland continental margin and their relationship to plate separation in the Northeast Atlantic - Earth and Planetary Science Letters 32: 149-157.

Soper, N.J., Higgins, A.C., Downie, C., Matthews, D.W. \& Brown, P.E., 1976b. Late Cretaceous - early Tertiary stratigraphy of the Kangerdlugssuaq area, east Greenland, and the age of opening of the north-east Atlantic - Journal of the Geological Society (London) 132: 85-104.

Stein, A.B., 1992. Seismic stratigraphy and seafloor morphology of the Kangerlugssuaq region, East Greenland: evidence for glaciations to the continental shelf break during the Late Weichselian 
and earlier - Unpublished master thesis University of Colorado: 292 pp.

Stewart, A.D., 1978. Stoer and Loch Assynt (Torridonian). In: Barber, A.J., Beach, A., Park, R.G., Tarney, J. \& Stewart, A.D. (eds.): The Lewisian and Torridonian rocks of North-West Scotland Geologists' Association Guide 21: 27-35.

Tobi, A.C. \& Kroll, H., 1975. Optical determination of the An-content of plagioclases twinned by Carlsbad-law: a revised chart American Journal of Science 275: 731-736.

Upton, B.G.J., Emeleus, C.H. \& Hald, N., 1980. Tertiary volcanism in northern E Greenland: Gauss Halvø and Hold with Hope
- Journal of the Geological Society (London) 137: 491-508.

Upton, B.G.J., Emeleus, C.H.\& Beckinsale, R.D., 1984. Petrology of the northern East Greenland Tertiary flood basalts: evidence from Hold with Hope and Wollaston Forland - Journal of Petrology 25: 151-184.

Wilson, J., 1989. Igneous petrogenesis - Unwin Hyman Ltd. (London): $\mathrm{xix}+466 \mathrm{pp}$.

Winchester, J.A., 1988. Later Proterozoic environments and tectonic evolution in the northern Atlantic lands. $I n$ : Winchester, J.A. (ed.): Later Proterozoic stratigraphy of the northern Atlantic regions - Blackie (Glasgow): 253-270. 